\title{
Tingkat Kerentanan Tepian Sungai Kayan Terhadap Bencana Banjir
}

\author{
Hendra Julianto ${ }^{1}$, Enny Harviyanti² \\ ${ }^{1}$ Jurusan Teknik Sipil Universitas Kaltara, Tanjung Selor \\ Email:hendra.julianto@gmail.com \\ ${ }^{2}$ Jurusan Teknik Sipil Universitas Kaltara, Tanjung Selor \\ Email:enny.harviyanti@yahoo.com
}

Bencana Banjir bukan hal luar biasa bagi warga Bulungan, terutama yang menetap di sekitar Daerah Aliran Sungai (DAS) Kayan. Namun Banjir 9 Februari 2015 ini benar-benar mengubah paradigma masyarakat kota Tanjung Selor tentang banjir. Banjir ini diakibatkan oleh luapan Sungai Kayan ditambah kiriman banjir dari Sabah, Malaysia yang mencapai ketinggian satu hingga tujuh meter. Banjir ini mengakibatkan kerugian-kerugian bagi warga kabupaten Bulungan terutama di lima kecamatan, yakni Kecamatan Peso, Kecamatan Peso Hilir, Kecamatan Tanjung Palas Barat, Kecamatan Tanjung Palas dan Kecamatan Tanjung Selor. Banjir ini menjadi pengingat betapa kuat kerusakan yang bisa menimpa Kota Tanjung Selor dan ke depan ancaman ini akan menjadi fenomena yang biasa terjadi akibat dampak perubahan iklim serta perubahan tata guna lahan. Dampak dari fenomena di atas akan menjadi fokus dari identifikasi tingkat kerentanan ini. Tujuannya adalah untuk mengetahui tingkat kerentanan tepian sungai kayan terhadap bencana banjir didasarkan pada kerentanan yang dikemukakan oleh IPCC 2014. Secara konseptual perhitungan kerentanan diadopsi dari kerangka berpikir IPCC 2014 di mana kerentanan (V) merupakan fungsi overlay dari sensitivitas (S) dan kapasitas adaptasi (AC) Sensitivitas (S) merupakan komponen yang akan terdampak oleh bencana banjir yaitu faktor fisik, sosial, ekonomi. Kapasitas adaptasi (AC) mengacu pada tindakan individu atau kolektif yang diambil untuk meminimalkan potensi dampak dari bahaya bencana banjir.. Metode penelitian yang digunakan adalah dengan melakukan skoring, pembobotan, clustering dan membuat peta dengan menggunakan ArGIS untuk memberikan gambaran tingkat kerentanan di tepian sungai Kayan terhadap bencana banjir. Berdasarkan hasil pengolahan data ditunjukkan bahwa tingkat kerentanan Tepian Sungai Kayan Terhadap Banjir dengan kerentanan tinggi terdapat pada 31 bangunan atau sekitar $35,90 \%$, tingkat kerentanan sedang sebanyak 35 bangunan atau sekitar 41,67\% dan tingkat kerentanan rendah sebanyak 18 bangunan atau sekitar 21,43\%.

Kata Kunci: Kerentanan, Keterpaparan, Sensitivitas, Kapasitas Adaptasi, Banjir

\section{PENDAHULUAN}

\subsection{Latar Belakang}

Fenomena perubahan iklim global yang terjadi belakangan ini memberikan pengaruh kepada masyarakat dan kawasan di berbagai belahan dunia termasuk di Indonesia. Perubahan iklim telah menyebabkan terjadinya peningkatan suhu global yang berdampak pada perubahan pola curah hujan, kenaikan muka air laut, serta meningkatnya kejadian cuaca ekstrem yang menyebabkan terjadinya bencana. Berdasarkan data statistik bencana di Indonesia 10 tahun terakhir (www.bnpb.go.id), banjir merupakan bencana alam yang paling sering kali terjadi dibandingkan dengan kejadian bencana alam lainnya seperti gempa, tsunami, kekeringan, longsor, dan lainnya.

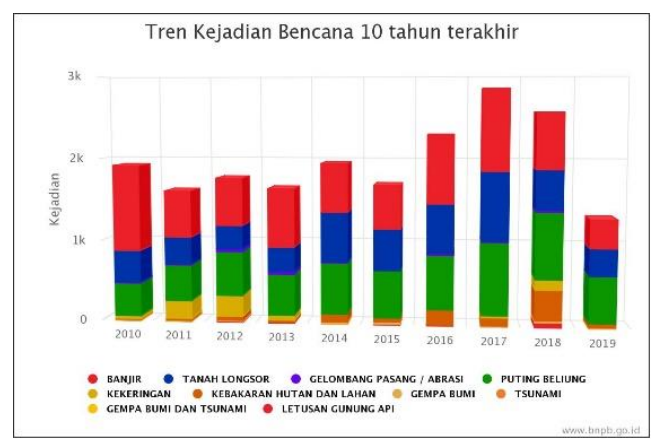

Gambar 1. Kejadian Bencana di Indonesia Tahun 2010-2019 (Sumber : www.bnpb.go.id)

Terjadinya akumulasi curah hujan tinggi dalam waktu yang singkat yang berdampak pada meningkatnya intensitas banjir yang terjadi. Kondisi ini diperparah dengan adanya beberapa faktor yang menyebabkan terjadinya banjir di antaranya perubahan tata guna lahan, sistem drainase yang tidak memadai, kurangnya kesadaran masyarakat di sepanjang alur sungai, penggundulan hutan di daerah hulu serta beberapa faktor lainnya. Banjir dengan skala yang luas, mendorong peluapan air di dataran rendah, sehingga banjir terjadi di sepanjang sistem sungai dan anak-anak sungainya. Seperti halnya banjir yang terjadi di sekitar aliran 
Sungai Kayan di Provinsi termuda di Indonesia, Provinsi Kalimantan Utara, tepatnya di Kota Tanjung Selor, Kabupaten Bulungan.

Kerentanan masyarakat terhadap dampak perubahan iklim dibentuk oleh dampak fisik dari bahaya iklim bersamaan dengan keterbatasan akses masyarakat untuk mendapatkan sumber daya untuk melepaskan atau memulihkan diri dari bencana dampak. Penilaian kerentanan dilakukan dengan tujuan untuk meningkatkan daya tahan kapasitas masyarakat dan untuk mengurangi risiko bahaya. Secara konseptual perhitungan kerentanan diadopsi dari kerangka berpikir IPCC (2014) di mana kerentanan (V) merupakan fungsi Sensitivitas (S) dan Kapasitas Adaptasi (AC). Sensitivitas merupakan komponen yang akan terdampak oleh bencana banjir yaitu faktor sosial, ekonomi, dan infrastruktur di tepian sungai Kayan. Kapasitas adaptasi mengacu pada kemampuan masyarakat untuk menghindari banjir seperti menaikkan lantai bangunan, membersihkan saluran air serta memiliki pemahaman terhadap bahaya banjir. Bencana banjir sebagai bagian dari keterpaparan (E) digambarkan sebagai bahaya banjir 9 Februari 2015 serta ditambahkan dengan ancaman pasang tertinggi yang mungkin terjadi.

\subsection{Rumusan Masalah}

Berdasarkan latar belakang yang telah diuraikan, permasalahan yang akan diteliti yaitu bagaimana tingkat kerentanan terhadap bencana banjir di tepian sungai Kayan Tanjung Selor?

\subsection{Tujuan Penelitian}

Tujuan penelitian ini adalah untuk mengetahui tingkat kerentanan tepian sungai Kayan dengan melakukan penilaian terhadap fungsi dari sensitivitas (S) dan kapasitas adaptasi (AC)

\subsection{Batasan Masalah}

Batasan masalah pada penelitian "Tingkat Kerentanan Tepian Sungai Kayan Tanjung Selor Terhadap Bencana Banjir” yaitu:

1. Hanya mengidentifikasi kerentanan bangunan di sisi jalan tepian sungai Kayan di Tanjung Selor, dari simpang Sengkawit sampai dengan Kampung Arab

2. Perhitungan kerentanan (Vulnerability) diadopsi dari kerangka berpikir IPCC (2014) dinyatakan sebagai fungsi dari Sensitivitas (Sensitivity) dan Kapasitas Adaptasi (Adaptive Capacity)

3. Tidak melakukan kajian bahaya banjir akan tetapi hanya mempelajari peta kerawanan banjir serta melakukan pengamatan di lapangan

\section{METODE PENELITIAN}

\subsection{Lokasi Penelitian}

Penelitian dilakukan di sepanjang tepian sungai Kayan yang berada di Kota Tanjung Selor, Kelurahan Tanjung Selor Hilir, Kecamatan Tanjung Selor, Kabupaten Bulungan, Provinsi Kalimantan Utara dimulai dari simpang Sengkawit (Tugu Damai) sampai dengan Kampung Arab dengan panjang mencapai $\pm 8 \mathrm{~km}$.

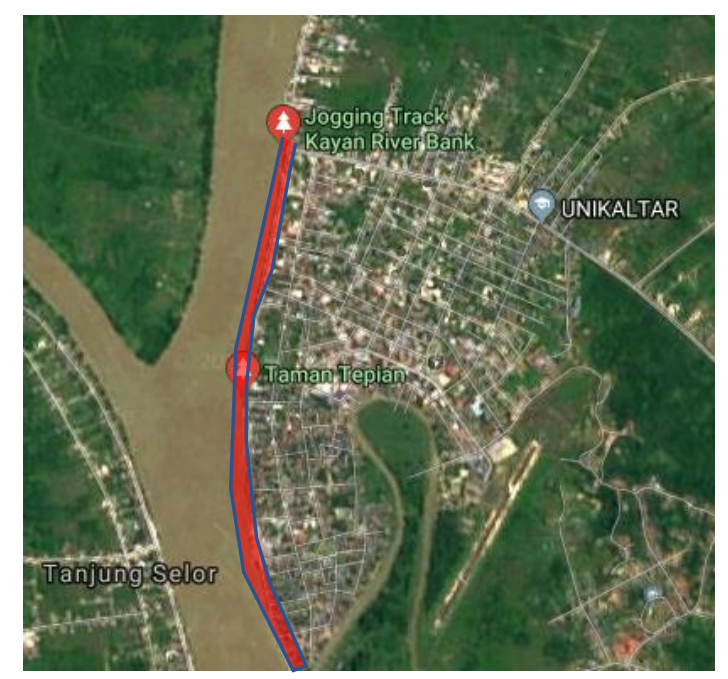

Gambar 2. Lokasi Penelitian di Tepian Sungai Kayan Tanjung Selor (Sumber : google earth) 


\subsection{Metodologi Penelitian}

Pendekatan dan metodologi yang akan digunakan pada dasarnya mencakup 4 (empat) tahapan pengerjaan yang meliputi :

1. Tahap Persiapan

Kegiatan persiapan ini terbagi 3 (tiga) bagian yaitu : (i) persiapan dasar, (ii) desk studi, dan (iii) survei pendahuluan.

2. Tahap Identifikasi

Tahapan ini merupakan rangkaian kegiatan survei lapangan, kompilasi dan analisis yang akan dilaksanakan sebagai tindak lanjut dari tahapan sebelumnya. Tahap ini diawali dengan kegiatan pengumpulan data dan survei yang bertujuan untuk mendapatkan gambaran nyata di daerah tepian sungai Kayan. Pengumpulan data yang akan dilakukan dalam survei ini dibagi atas dua kelompok besar, yaitu pengumpulan data sekunder terkait dengan peta dan dokumen terkait serta pengumpulan data primer dengan menggunakan kuesioner/wawancara serta melakukan dokumentasi. Kuesioner terdiri dari 3 bagian pertanyaan inti yaitu pertanyaan terkait dengan keterpaparan, sensitivitas dan kapasitas adaptasi. Pertanyaan keterpaparan terkait dengan ancaman bencana banjir. Pertanyaan sensitivitas terkait komponen yang akan terdampak oleh bencana banjir yaitu faktor fisik, sosial, ekonomi. Pertanyaan kapasitas adaptasi mengacu pada tindakan individu atau kolektif yang diambil untuk meminimalkan potensi dampak dari bahaya bencana banjir. Berdasarkan perhitungan menggunakan rumus Slovin, ditetapkan jumlah sampel sebanyak 84 responden/bangunan dari 152 populasi/bangunan. Data primer yang dibutuhkan adalah data terkait dengan kerentanan di tepian Sungai Kayan terhadap banjir yang meliputi komponen keterpaparan (E), sensitivitas (S) dan kapasitas adaptasi (AC).

3. Tahap Analisis

Rumus yang digunakan dalam penelitian ini adalah sebagai berikut :

Indeks Keterpaparan

$(\mathrm{EI})=(\mathrm{E} 1+\mathrm{E} 2+\mathrm{E} 3) / 3$

Indeks Sensitivitas $(\mathrm{SI})=(\mathrm{S} 1 / 5+\mathrm{S} 2 / 4+\mathrm{S} 3 / 3)$

Indeks Kapasitas Adaptasi

$(\mathrm{ACI})=(\mathrm{AC} 1+\mathrm{AC} 2) / 2$

Indeks Kerentanan

$\mathrm{VI}=(\mathrm{EI}+\mathrm{SI})-\mathrm{ACI}$

Variabel kerentanan terpilih, akan diukur dengan memberikan skor. Setelah dilakukan skoring, maka tiap-tiap variabel kerentanan akan diberi bobot. Hasil perkalian antara skor dan bobot pada variabel tingkat sensitivitas merupakan Indeks Sensitivitas (SI), sedangkan hasil perkalian antara skor dan bobot pada variabel kapasitas adaptasi merupakan Indeks Kapasitas Adaptasi (ACI). Setelah didapat penilaian pada sensitivitas (S), dan Kapasitas Adaptasi (AC), selanjutnya dilakukan clustering dengan metode perhitungan K-mean dengan tahapan sebagai berikut:

a. Kelompokkan data menjadi 3 dataset atau 3 kelas.

b. Setelah menentukan kelas atau dataset, maka perlu menentukan jumlah cluster yang akan dibentuk

c. Tetapkan C pusat cluster awal secara random

d. Alokasikan semua data/obyek ke dalam cluster terdekat. Adapun hasil dari jarak ke cluster diperoleh dari perhitungan dengan rumus :

$$
d(x, y)=\sqrt{\sum_{i=1}^{n}\left(x_{i}-y_{i}\right)^{2}}
$$

e. Hitung semua data dengan cara dikalikan dengan pusat cluster

f. Lakukan terus perhitungan hingga dua iterasi memiliki hasil yang sama.

Analisis ini merupakan salah satu alat analisis yang digunakan untuk mengetahui tingkat sensitivitas (S) dan tingkat kapasitas adaptasi (AC) untuk mencapai tujuan penelitian yakni mengetahui tingkat kerentanan yang dibagi menjadi 3 kategori, yaitu: kerentanan rendah (low), kerentanan sedang (moderate), kerentanan tinggi (high). Tahap selanjutnya yaitu membuat pemodelan spasial baru untuk view atau representasi peta digital tingkat sensitivitas, tingkat kapasitas dan tingkat kerentanan tepian sungai Kayan terhadap banjir

4. Tahap Finalisasi

Target yang ingin dicapai pada tahap finalisasi yaitu tersusunnya produk berupa laporan tingkat kerentanan tepian sungai Kayan terhadap bencana banjir dan tersedianya media informasi produk berupa peta 


\section{HASIL DAN PEMBAHASAN}

\subsection{Banjir di Tepian Sungai Kayan}

Terjadinya banjir di Tanjung Selor khususnya di tepian sungai kayan semakin meningkat seiring dengan bertambahnya kegiatan perubahan tata guna lahan yang ada, curah hujan yang tinggi, drainase yang tidak memadai, serta meningkatnya pasang air laut. Berikut adalah data kejadian banjir Kalimantan Utara.

Tabel. 1. Waktu Kejadian Terjadinya Banjir

\begin{tabular}{|c|c|c|c|}
\hline Waktu & Lokasi & Kedalaman & Lama Genangan \\
\hline $12-02-2015$ & Kec Long Peso & $60 \mathrm{Cm}$ & 4 Hari \\
\hline $05-04-2017$ & Tanjung Selor & $10-60 \mathrm{Cm}$ & 2 Hari \\
\hline $10-05-2017$ & Kec Tanjung Palas & $1-2 \mathrm{M}$ & 1 Hari \\
\hline
\end{tabular}

Sumber :Tribun news. com dalam Soko Negoro, 2018

Berdasarkan dari waktu kejadian terjadinya banjir, maka daerah yang memiliki potensi banjir yang cukup besar adalah di daerah hilir sungai tepatnya di daerah Tanjung Selor. Berikut adalah peta rawan banjir wilayah sungai Kayan Tanjung Selor yang diperoleh dari Bidang Sumber Daya Air Dinas PU dan Tata Ruang Pemerintah Provinsi Kalimantan Utara.

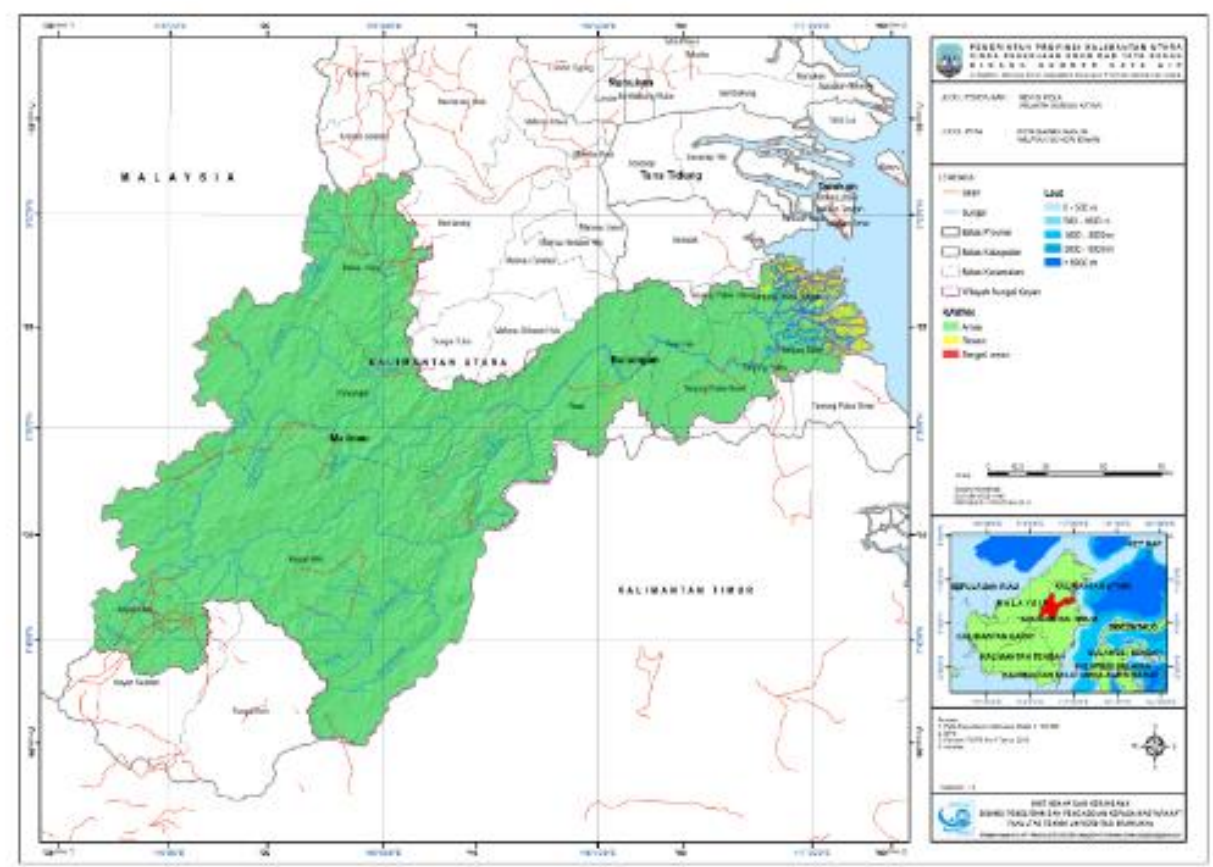

Gambar 3 Peta Rawan Banjir di Tepian Sungai Kayan (Sumber : Bidang SDA PUTR Prov.Kaltara)

Banjir yang terjadi pada 9 Februari 2015 ini merupakan banjir terburuk yang pernah terjadi. Banjir ini diakibatkan oleh luapan Sungai Kayan ditambah kiriman banjir dari Sabah, Malaysia. Ketinggian air rata-rata mencapai satu meter dan bahkan ada satu kawasan yang bahkan mencapai tujuh meter. Banjir di tepian sungai kayan digambarkan pada sebaran banjir sebagai berikut: 


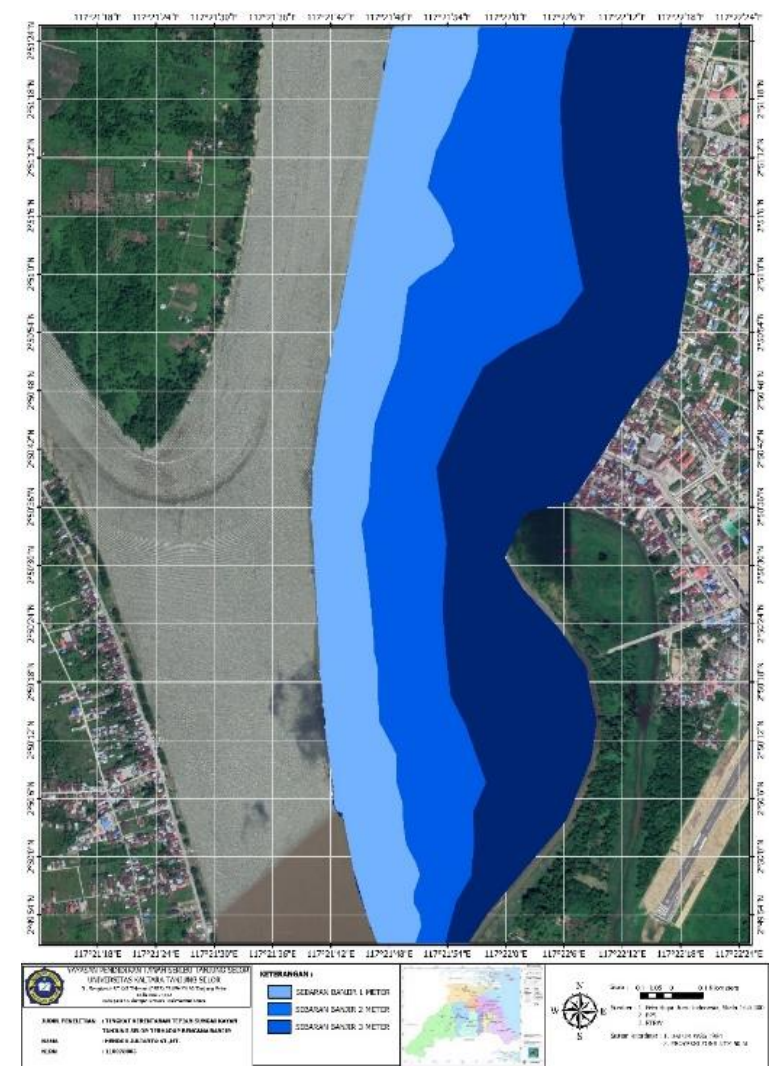

Gambar 4 Peta Sebaran Banjir di Tepian Sungai Kayan (1-3 m)

\subsection{Kajian Kerentanan}

Pengolahan data kerentanan dimulai dengan melakukan skoring pada masing-masing jawaban kuesioner kemudian dilakukan pembobotan. Tahap berikutnya di lakukan perhitungan untuk mencari nilai kerentanan di tepian sungai Kayan diperoleh hasil sebagai berikut:

Tabel 2 Hasil Rekapitulasi Penilaian Kerentanan

\begin{tabular}{|r|r|r|r|r|r|r|r|}
\hline \multicolumn{7}{|c|}{ Kerentanan (V) } \\
\hline No. & SXB & No. & SXB & No. & SXB & No. & SXB \\
\hline $\mathbf{1}$ & 14.92 & $\mathbf{2 2}$ & 15.87 & $\mathbf{4 3}$ & 11.75 & $\mathbf{6 4}$ & 20.85 \\
\hline $\mathbf{2}$ & 11.30 & $\mathbf{2 3}$ & 12.63 & $\mathbf{4 4}$ & 21.45 & $\mathbf{6 5}$ & 20.70 \\
\hline $\mathbf{3}$ & 13.70 & $\mathbf{2 4}$ & 15.80 & $\mathbf{4 5}$ & 20.60 & $\mathbf{6 6}$ & 16.12 \\
\hline $\mathbf{4}$ & 13.70 & $\mathbf{2 5}$ & 18.20 & $\mathbf{4 6}$ & 22.67 & $\mathbf{6 7}$ & 14.45 \\
\hline $\mathbf{5}$ & 12.50 & $\mathbf{2 6}$ & 16.20 & $\mathbf{4 7}$ & 24.25 & $\mathbf{6 8}$ & 16.78 \\
\hline $\mathbf{6}$ & 18.82 & $\mathbf{2 7}$ & 14.42 & $\mathbf{4 8}$ & 19.72 & $\mathbf{6 9}$ & 17.03 \\
\hline $\mathbf{7}$ & 15.75 & $\mathbf{2 8}$ & 17.55 & $\mathbf{4 9}$ & 20.17 & $\mathbf{7 0}$ & 16.78 \\
\hline $\mathbf{8}$ & 15.17 & $\mathbf{2 9}$ & 16.25 & $\mathbf{5 0}$ & 22.20 & $\mathbf{7 1}$ & 16.78 \\
\hline $\mathbf{9}$ & 19.50 & $\mathbf{3 0}$ & 15.08 & $\mathbf{5 1}$ & 20.93 & $\mathbf{7 2}$ & 21.87 \\
\hline $\mathbf{1 0}$ & 14.42 & $\mathbf{3 1}$ & 14.70 & $\mathbf{5 2}$ & 20.08 & $\mathbf{7 3}$ & 21.32 \\
\hline $\mathbf{1 1}$ & 17.00 & $\mathbf{3 2}$ & 10.97 & $\mathbf{5 3}$ & 20.07 & $\mathbf{7 4}$ & 20.78 \\
\hline $\mathbf{1 2}$ & 15.00 & $\mathbf{3 3}$ & 10.30 & $\mathbf{5 4}$ & 19.38 & $\mathbf{7 5}$ & 18.67 \\
\hline $\mathbf{1 3}$ & 20.30 & $\mathbf{3 4}$ & 19.17 & $\mathbf{5 5}$ & 18.13 & $\mathbf{7 6}$ & 21.72 \\
\hline $\mathbf{1 4}$ & 20.37 & $\mathbf{3 5}$ & 16.00 & $\mathbf{5 6}$ & 15.40 & $\mathbf{7 7}$ & 22.92 \\
\hline $\mathbf{1 5}$ & 22.50 & $\mathbf{3 6}$ & 9.10 & $\mathbf{5 7}$ & 14.45 & $\mathbf{7 8}$ & 16.78 \\
\hline $\mathbf{1 6}$ & 18.75 & $\mathbf{3 7}$ & 16.00 & $\mathbf{5 8}$ & 13.25 & $\mathbf{7 9}$ & 17.92 \\
\hline $\mathbf{1 7}$ & 14.55 & $\mathbf{3 8}$ & 11.75 & $\mathbf{5 9}$ & 18.23 & $\mathbf{8 0}$ & 20.53 \\
\hline $\mathbf{1 8}$ & 10.55 & $\mathbf{3 9}$ & 11.50 & $\mathbf{6 0}$ & 20.17 & $\mathbf{8 1}$ & 18.78 \\
\hline $\mathbf{1 9}$ & 11.75 & $\mathbf{4 0}$ & 11.75 & $\mathbf{6 1}$ & 16.98 & $\mathbf{8 2}$ & 18.45 \\
\hline $\mathbf{2 0}$ & 12.30 & $\mathbf{4 1}$ & 10.30 & $\mathbf{6 2}$ & 21.50 & $\mathbf{8 3}$ & 16.78 \\
\hline $\mathbf{2 1}$ & 16.75 & 42 & 10.55 & $\mathbf{6 3}$ & 20.65 & $\mathbf{8 4}$ & 18.20 \\
\hline
\end{tabular}


Selanjutnya dilakukan pengelompokan dengan menggunakan K-Mean ke dalam 3 kelompok untuk masing-masing tingkat sensitivitas (S), tingkat kapasitas adaptasi (AC) dan tingkat kerentanan (V) di tepian sungai Kayan. Berdasarkan hasil pengolahan data diperoleh sebagai berikut:

Tabel 3 Hasil Rekapitulasi Cluster dengan Metode $K$-Mean

\begin{tabular}{|c|c|c|c|c|c|c|c|c|c|c|c|c|c|c|c|}
\hline $\mathbf{R}$ & $\mathrm{s}$ & AC & v & $\mathbf{R}$ & $\mathrm{S}$ & AC & v & $\mathbf{R}$ & $\mathbf{S}$ & $A C$ & v & $\mathbf{R}$ & $\mathrm{S}$ & AC & v \\
\hline 1 & SEDANG & EANG & EDANG & $22 \mathrm{~s}$ & SEDANG & SEDANG & SEDANG & 43 & TINGGI & SEDANG & RENDAH & 64 & TINGGI & SEDANG & TINGGI \\
\hline 2 & ENDAH & SEDANG & RENDAH & $23 \mathrm{~s}$ & SEDANG & SEDANG & RENDAH & 44 & TINGGI & SEDANG & TINGGI & 65 & SEDANG & SEDANG & TINGGI \\
\hline 3 & RENDAH & SEDANG & RENDAH & $24 \mathrm{~F}$ & RENDAH & SEDANG & SEDANG & 45 & TINGGI & SEDANG & TINGGI & $66 s$ & SEDANG & SEDANG & SEDANG \\
\hline 4 & ENDAH & SEDANG & RENDAH & $25 S$ & SEDANG & SEDANG & SEDANG & 46 & TINGGI & SEDANG & TINGGI & 675 & SEDANG & SEDANG & SEDANG \\
\hline 5 & RENDAH & SEDANG & RENDAH & $26 \mathrm{~S}$ & SEDANG & TINGGI & SEDANG & 47 & TINGGI & SEDANG & TINGGI & 685 & SEDANG & SEDANG & SEDANG \\
\hline 6 & SEDANG & SEDANG & TINGGI & $27 \mathrm{~s}$ & SEDANG & SEDANG & SEDANG & 48 & TINGGI & SEDANG & TINGGI & 695 & SEDANG & SEDANG & SEDANG \\
\hline 7 & SEDANG & SEDANG & SEDANG & $28 \mathrm{~S}$ & SEDANG & SEDANG & SEDANG & 49 & TINGGI & SEDANG & TINGGI & 705 & SEDANG & SEDANG & SEDANG \\
\hline 8 & SEDANG & SEDANG & SEDANG & $29 \mathrm{~S}$ & SEDANG & TINGGI & SEDANG & 50 & TINGGI & SEDANG & TINGGI & 715 & SEDANG & SEDANG & SEDANG \\
\hline 9 & TINGGI & SEDANG & TINGGI & $30 \mathrm{~s}$ & SEDANG & SEDANG & SEDANG & 51 & TINGGI & SEDANG & TINGGI & 727 & TINGGI & SEDANG & TINGGI \\
\hline 10 & SEDANG & SEDANG & SEDANG & $31 \mathrm{~s}$ & SEDANG & SEDANG & SEDANG & 52 & TINGGI & SEDANG & TINGGI & 737 & TINGGI & SEDANG & TINGGI \\
\hline 11 & SEDANG & SEDANG & SEDANG & $32 \mathrm{~s}$ & SEDANG & SEDANG & RENDAH & 53 & TINGGI & SEDANG & TINGGI & 747 & TINGGI & SEDANG & TINGGI \\
\hline 12 & SEDANG & SEDANG & SEDANG & $33 \mathrm{~F}$ & RENDAH & SEDANG & RENDAH & 54 & SEDANG & SEDANG & TINGGI & $75 S$ & SEDANG & SEDANG & TINGGI \\
\hline 13 & TINGGI & SEDANG & TINGGI & $34 \mathrm{~F}$ & RENDAH & SEDANG & TINGGI & 55 & SEDANG & SEDANG & SEDANG & 76 & TINGGI & SEDANG & TINGGI \\
\hline 14 & TINGGI & SEDANG & TINGGI & $\begin{array}{lll}35 & 1 \\
\end{array}$ & TINGGI & TINGGI & SEDANG & 56 & SEDANG & SEDANG & SEDANG & 771 & TINGGI & SEDANG & TINGGI \\
\hline 15 & TINGGI & SEDANG & TINGGI & $36 \mathrm{~s}$ & SEDANG & SEDANG & RENDAH & 57 & RENDAH & SEDANG & SEDANG & 785 & SEDANG & SEDANG & SEDANG \\
\hline 16 & SEDANG & SEDANG & TINGGI & $37 \mathrm{~F}$ & RENDAH & TINGGI & SEDANG & 58 & SEDANG & SEDANG & RENDAH & 795 & SEDANG & SEDANG & SEDANG \\
\hline 17 & RENDAH & RENDAH & SEDANG & $38 \mathrm{~F}$ & RENDAH & SEDANG & RENDAH & 59 & TINGGI & SEDANG & SEDANG & 807 & TINGGI & SEDANG & TINGGI \\
\hline 18 & RENDAH & SEDANG & RENDAH & $39 \mathrm{~F}$ & RENDAH & SEDANG & RENDAH & 60 & SEDANG & SEDANG & TINGGI & 815 & SEDANG & SEDANG & TINGGI \\
\hline 19 & RENDAH & SEDANG & RENDAH & $40 \mathrm{~F}$ & RENDAH & SEDANG & RENDAH & 61 & TINGGI & SEDANG & SEDANG & 825 & SEDANG & SEDANG & SEDANG \\
\hline 20 & RENDAH & SEDANG & RENDAH & $41 \mathrm{~F}$ & RENDAH & SEDANG & RENDAH & 62 & TINGGI & SEDANG & TINGGI & 835 & SEDANG & SEDANG & SEDANG \\
\hline 21 & RENDAH & SEDANG & SEDANG & $42 \mathrm{~F}$ & RENDAH & SEDANG & RENDAH & 63 & TINGGI & SEDANG & TINGGI & 84 & SEDANG & SEDANG & SEDANG \\
\hline
\end{tabular}

Dari hasil cluster di atas kemudian diketahui bahwa tingkat sensitivitas rendah baik fisik, sosial dan ekonomi terdiri dari 19 bangunan atau $22,62 \%$, sensitivitas sedang terdiri dari 38 bangunan atau sebesar $45,24 \%$ dan tingkat sensitivitas tinggi terdiri dari 27 bangunan atau 32,14\%. Dengan demikian secara keseluruhan kondisi internal baik fisik, sosial, dan ekonomi di Tepian Sungai kayan mayoritas menunjukkan tingkat kerawanan yang sedang terhadap gangguan bencana banjir.

Tabel 4 Tingkat Sensitivitas (S) Tepian Sungai Kayan Terhadap Banjir

\begin{tabular}{|c|c|c|}
\hline Klasifikasi & Jumlah Responden/Bangunan & $\begin{array}{c}\text { Persentase } \\
(\mathbf{\%})\end{array}$ \\
\hline Rendah & 19 & 22.62 \\
\hline Sedang & 38 & 45.24 \\
\hline Tinggi & 27 & 32.14 \\
\hline Total & 84 & 100 \\
\hline
\end{tabular}

Sebagai gambaran tingkat sensitivitas bangunan di tepian sungai kayan terhadap banjir dapat dilihat pada gambar 5 . 


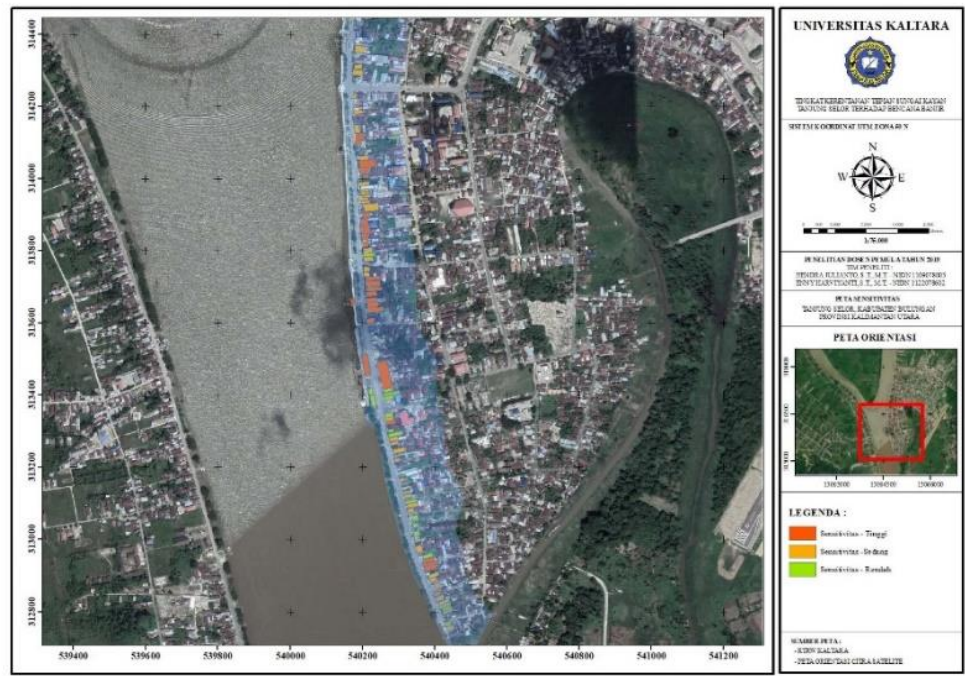

Gambar 5 Peta Tingkat Sensitivitas (S) Tepian Sungai Kayan Terhadap Banjir

Hasil dari pengelompokan data menggunakan $K$-mean menunjukkan bahwa hampir sebagian besar bangunan di tepian sungai Kayan telah melakukan peningkatan kapasitas adaptasi terhadap adanya bahaya banjir. Jumlah bangunan dengan tingkat kapasitas adaptasi sedang sebanyak 81 bangunan atau sebesar $96.43 \%$ sedangkan tingkat kapasitas tinggi hanya 3 bangunan atau 3,57\% serta tidak ditemukannya bangunan yang tidak meningkatkan kapasitas adaptasi terhadap adanya bahaya banjir.

Tabel 5. Tingkat Kapasitas Adaptasi (AC)Tepian Sungai Kayan Terhadap Banjir

\begin{tabular}{|c|c|c|}
\hline Klasifikasi & $\begin{array}{c}\text { Jumlah } \\
\text { Responden/ } \\
\text { Bangunan }\end{array}$ & $\begin{array}{c}\text { Persentase } \\
(\boldsymbol{\%})\end{array}$ \\
\hline Rendah & 0 & 0.00 \\
\hline Sedang & 81 & 96.43 \\
\hline Tinggi & 3 & 3.57 \\
\hline Total & 84 & 100.00 \\
\hline
\end{tabular}

Gambaran peta kapasitas adaptasi (AC) dapat dilihat pada gambar 6.

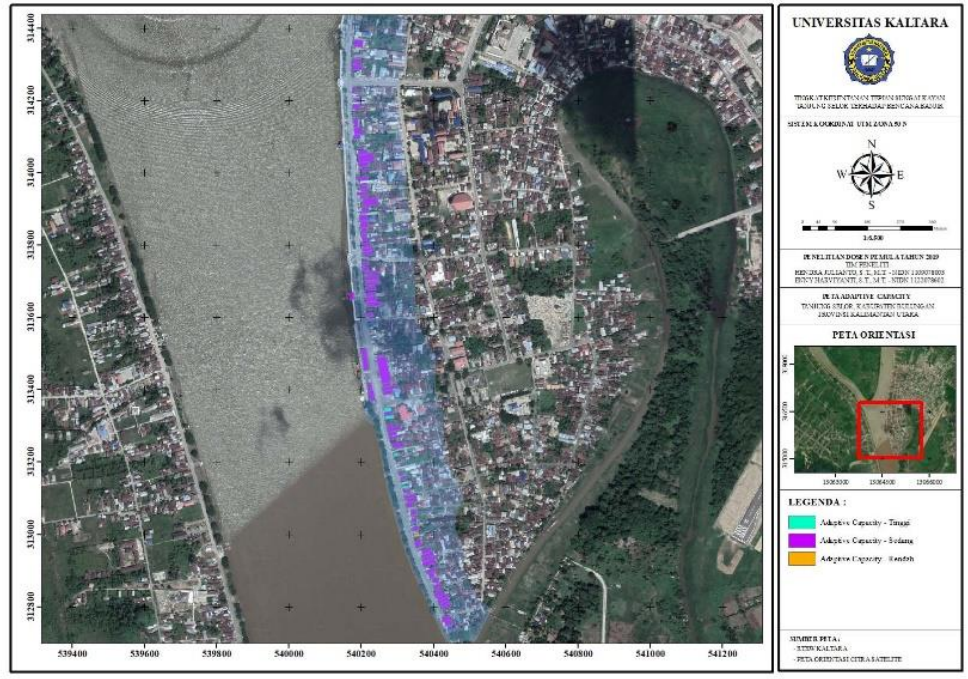

Gambar 6 Peta Tingkat Kapasitas Adaptasi (AC) Tepian Sungai Kayan Terhadap Banjir

Berdasarkan hasil pengolahan data terhadap fungsi sensitivitas (S) dan kapasitas adaptasi (AC) diperoleh hasil bahwa tingkat kerentanan (V) tepian sungai Kayan terhadap banjir dengan kerentanan tinggi terdapat pada 31 bangunan atau sekitar 35,90\%, tingkat kerentanan sedang sebanyak 35 bangunan atau sekitar 41,67\% dan tingkat kerentanan rendah sebanyak 18 bangunan atau sekitar 21,43\%. Hal ini menunjukkan bahwa tepian sungai Kayan sebagian besar memiliki kerentanan yang sedang. 
Tabel 6. Tingkat Kerentanan (V) Tepian Sungai Kayan Terhadap Bencana Banjir

\begin{tabular}{|c|c|c|}
\hline Klasifikasi & $\begin{array}{c}\text { Jumlah } \\
\text { Responden/ } \\
\text { Bangunan }\end{array}$ & $\begin{array}{c}\text { Presentase } \\
(\boldsymbol{\%})\end{array}$ \\
\hline Rendah & 18 & 21.43 \\
\hline Sedang & 35 & 41.67 \\
\hline Tinggi & 31 & 36.90 \\
\hline Total & 84 & 100.00 \\
\hline
\end{tabular}

Secara lengkap gambaran kerentanan tepian sungai Kayan dapat dilihat pada gambar 7 .

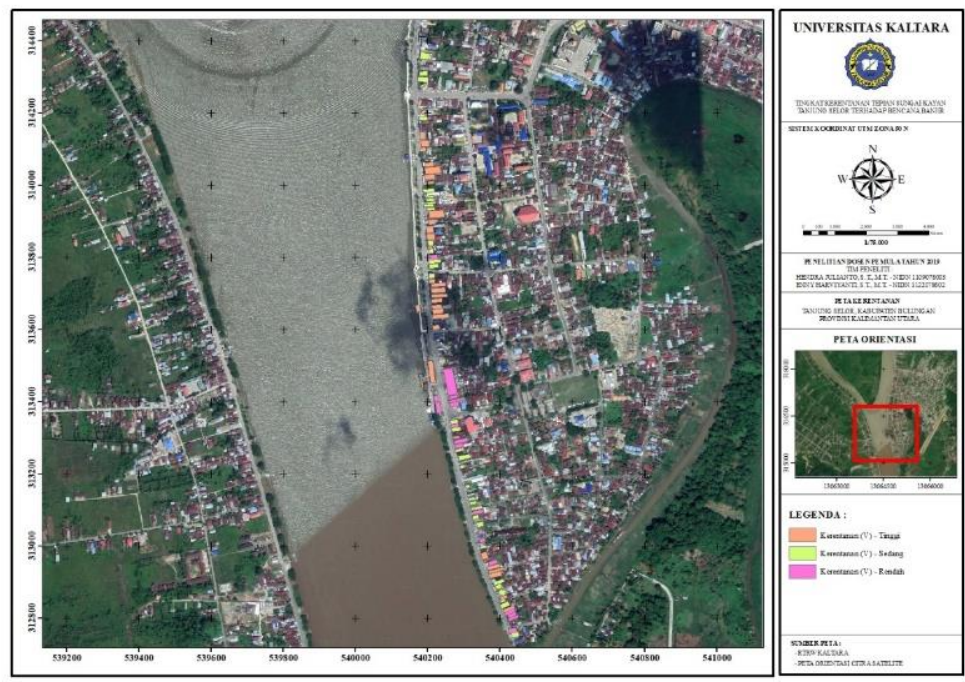

Gambar 7 Peta Tingkat Kerentanan (V) Tepian Sungai Kayan Terhadap Banjir

\section{KESIMPULAN DAN SARAN}

\subsection{Kesimpulan}

Berdasarkan hasil dan pembahasan di atas maka dapat disimpulkan sebagai berikut:

1. Tingkat sensitivitas rendah terdiri dari 19 bangunan atau $22,62 \%$, sensitivitas sedang terdiri dari 38 bangunan atau sebesar 45,24\% dan tingkat sensitivitas tinggi terdiri dari 27 bangunan atau 32,14\%.

2. Tingkat kapasitas adaptasi sedang sebanyak 81 atau sebesar $96.43 \%$ sedangkan tingkat kapasitas tinggi hanya 3 bangunan atau 3,57\%, serta tidak ditemukannya bangunan yang tidak meningkatkan kapasitas adaptasi terhadap adanya bencana banjir.

3. Tingkat kerentanan tepian sungai Kayan terhadap banjir dengan kerentanan tinggi terdapat pada 31 bangunan atau sekitar $35,90 \%$, tingkat kerentanan sedang sebanyak 35 bangunan atau sekitar 41,67\% dan tingkat kerentanan rendah sebanyak 18 bangunan atau sekitar $21,43 \%$.

\subsection{Saran}

Penelitian ini sebaiknya ditindaklanjuti dengan penelitian berikutnya yaitu kajian bahaya (H) dan kajian risiko (R) untuk mendapatkan peta risiko bencana.

\section{DAFTAR PUSTAKA}

[1]. Adhe Reza Rachmat dan Adjie Pamungkas, 2016: Faktor-Faktor Kerentanan yang Berpengaruh Terhadap Bencana Banjir di Kecamatan Manggala Kota Makassar Banjir yang terjadi di Kecamatan Manggala.

[2]. Dian Adhietya Arif, Djati Mardiatna dan Sri Rum Giyarsih , 2014: Kerentanan Masyarakat Perkotaan terhadap Bahaya Banjir di Kelurahan Legok, Kecamatan Telanipura, Kota Jambi.

[3]. Iwan Rudiarto,Dony Pamungkas, Hajar Annisa A dan Khalid Adam, 2017: Kerentanan Sosio-Ekonomi terhadap Paparan Bencana Banjir dan Rob di Pedesaan Pesisir Kabupaten Demak. 
[4]. Setiawan, Budhi, Puspita, Norma dan Setiojati, Ambiyar, 2010, Vulnerability Assessment of Urban Infrastructure

[5]. htttps://www.BNPB.co.id

[6]. https://www.google.com/earth/

[7]. IPCC 2007, Climate Change 2007: The Project Science Basis. Contribution of Working Group I to the Fourth Assessment Report of the Intergovernmental Panel on Climate Change.

[8]. IPCC 2014: Impacts, Adaptation, and Vulnerability 